\title{
KEY MARKETING CONCEPTS
}

Mike Meldrum

and

Malcolm McDonald

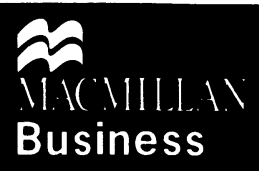


(C) Mike Meldrum and Malcolm McDonald 1995

All rights reserved. No reproduction, copy or transmission of this publication may be made without written permission.

No paragraph of this publication may be reproduced, copied or transmitted save with written permission or in accordance with the provisions of the Copyright, Designs and Patents Act 1988, or under the terms of any licence permitting limited copying issued by the Copyright Licensing Agency, 90 Tottenham Court Road, London W1P 9HE.

Any person who does any unauthorised act in relation to this publication may be liable to criminal prosecution and civil claims for damages.

First published 1995 by MACMILLAN PRESS LTD

Houndmills, Basingstoke, Hampshire RG21 6XS

and London

Companies and representatives

throughout the world

ISBN 978-0-333-64563-5

ISBN 978-1-349-13877-7 (eBook) DOI 10.1007/978-1-349-13877-7

A catalogue record for this book is available from the British Library.

$\begin{array}{rrrrrrrrrr}10 & 9 & 8 & 7 & 6 & 5 & 4 & 3 & 2 & 1 \\ 04 & 03 & 00 & 01 & 00 & 99 & 98 & 97 & 96 & 95\end{array}$

Copy-edited and typeset by Povey-Edmondson

Okehampton and Rochdale, England 


\section{Contents}

List of Tables vii

List of Figures viii

Foreword $\mathbf{x}$

Checklist of Concepts $\quad \mathrm{xi}$

Group A Understanding the Basics of Marketing 1

1 Understanding Marketing 3

2 A Marketing Orientation 7

3 The Marketing Mix 11

4 International Marketing 17

5 Relationship Marketing 21

6 Marketing and Ethics 27

Group B Understanding Different Forms of Marketing

7 Marketing Consumer Products (by S. Knox) 33

8 Marketing Industrial Products 37

9 Marketing Service Products 41

10 Marketing High-tech Products 47

11 Trade Marketing (by M. Jenkins) 53

12 Marketing Capital Goods 57

Group C Understanding Markets and Competitors 61

13 Marketing Information and Research 63

14 Preparing the Marketing Research Brief and Proposal 69

15 Auditing a Market 73

16 Constructing a SWOT 77

17 Market Segmentation 83

18 International Market Segmentation 87

19 Competitor Analysis 91

20 Consumer Buying Behaviour 97

21 Organisational Buyer Behaviour 103 
Group D Understanding Product Management 109

22 The Product Life-cycle 111

23 Diffusion of Innovation 117

24 The Ansoff Matrix 121

25 The Boston Matrix 127

26 The Directional Policy Matrix 133

27 Developing New Products 141

Group E Understanding Positioning 147

28 Branding 149

29 Pricing Strategies 153

30 Setting a Price 159

31 Advertising 163

32 Public Relations 169

Group F Understanding Marketing Relationships 173

33 Personal Selling 175

34 Managing the Sales Team 179

35 Channel Strategy 185

36 Channel Management 189

37 Sales Promotion 193

38 Customer Retention Strategies 199

39 Customer Service Strategies 205

40 Database Marketing 209

Group G Understanding Marketing Planning and Control 217

41 Forecasting Future Sales 219

42 Marketing Planning 225

43 International Product Planning 231

44 Organisational Structure and Marketing 237

45 Budgeting for Marketing 243 


\section{List of Tables}

3.1 Product variables $\quad 12$

$\begin{array}{ll}3.2 & \text { Pricing variables } \\ & 12\end{array}$

4.1 Environment differences when marketing overseas 18

4.2 Key questions in international marketing 20

5.1 Tendencies inherent in a transaction approach to marketing 21

9.1 Major examples of service industries 41

9.2 Variations in product tangibility 42

13.1 Main areas of market research 64

13.2 Top ten marketing research topics 64

15.1 The marketing audit checklist 75

19.1 Guide to market competitive position classifications 93

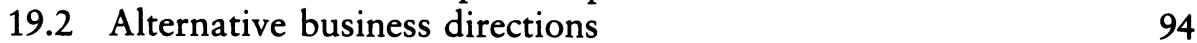

19.3 Individual competitor analysis 95

22.1 Typical marketing-mix strategies for different life-cycle stages

$\begin{array}{lll}24.1 & \text { Kinds of new products and markets } & 125 \\ 26.1 & \text { Criteria which might make a market attractive } & 135\end{array}$

26.2 Factors which might be considered, or which may yield, business strengths

26.3 The ten steps involved in producing a DPM 138

28.1 Bipolar scales for brand positioning 151

29.1 Appeal of a cost approach to pricing 157

29.2 Problems of a cost approach to pricing 157

31.1 Suggested pro-forma for an advertising plan 166

33.1 The advantages of personal selling 178

34.1 Further quantitative objectives for a sales force 180

34.2 Setting objectives for an individual sales representative 181

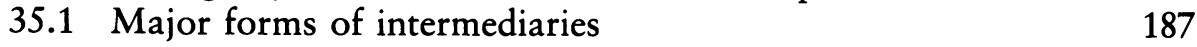

37.1 Types of sales promotions 195

38.1 Industries with traditionally high defection rates, where customer retention improvements can have a significant impact

40.1 Myths and realities about databases 210

40.2 Problems of reconciling internal and external market audits 211

40.3 Examples of business objectives and segmentation methods 213

40.4 The main components of a market database system 215

43.1 Areas requiring attention in international product planning 235 


\section{List of Figures}

3.1 Channel possibilities, for the produce of a market gardener 15

5.1 Expanded marketing mix 23

5.2 The relationship marketing six markets model 24

6.1 Consumerism's way to better marketing 30

$\begin{array}{ll}7.1 \text { The components of a brand } & 35\end{array}$

7.2 The consumer's decision environment 35

8.1 Continuum of industrial marketing 38

9.1 Continuum of tangible-intangible possibilities 43

10.1 The technology life-cycle 50

11.1 The trend towards supplier-retailer convergence 54

16.1 Establishing competitive positions using critical success 79

$\begin{array}{ll}16.2 \text { Strengths and weaknesses analysis } & 79\end{array}$

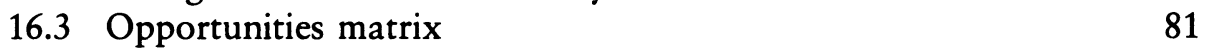

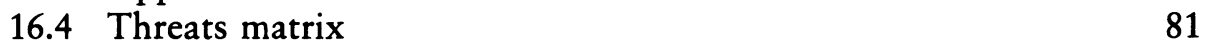

17.1 Example of segmentation of toothpaste market 85

19.1 Competitor analysis $\quad 94$

20.1 Components of a consumer's purchase decision 98

$\begin{array}{ll}21.1 & \text { Organisational buying behaviour model } \\ & 104\end{array}$

22.1 Standard product life-cycle curve 111

22.2 Phases in the product life-cycle 113

$\begin{array}{ll}22.3 \text { Alternative product life-cycle } & 115\end{array}$

23.1 The diffusion of the innovation curve 118

24.1 The Ansoff Matrix 122

24.2 An extended product/market matrix 126

25.1 The Boston Matrix 127

25.2 The experience curve 128

25.3 The Boston Matrix - cash-flow implications 130

26.1 The Directional Policy Matrix (DPM) 133

26.2 Four strategic categories 137

26.3 Programme guidelines suggested for different positioning on
the DPM

27.1 New product classification $\quad 142$

27.2 Cultural blockages to new product initiatives 144

$\begin{array}{ll}27.3 \text { Risk and new product development } & 145\end{array}$

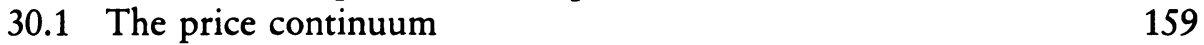


39.1 Example of customer service trade-off matrix

40.1 Information flows in a marketing system

42.1 Strategic and tactical marketing plans

42.2 Strategic and operational planning cycle

230

44.1 Organisational structure and marketing 


\section{Foreword}

This book was produced to meet a clear need expressed by many people for a series of concise summaries or overviews of marketing principles, concepts, tools and techniques. It is not a textbook or reader which needs to be studied cover to cover, but a work of reference for those wishing to familiarise or refamiliarise themselves with the essence of a particular aspect of marketing.

Each piece is a stand-alone coverage of an important concept in marketing which presents the essential features of that concept in a straightforward manner. It assumes some previous exposure to marketing, either from practical experience of working in an organisation or from some past or present study. It does not, however, assume any expertise on the part of the reader.

The book is, therefore, a quick and efficient reference for busy practising managers who do not have the time to go through a whole book to find the concept they need. It can also be used as a revision text for those studying marketing in some form or another. It is an excellent accompaniment to short courses on marketing.

To review a particular area in marketing, the reader simply refers to that group and selects the concept or concepts in which they are most interested. As an example, anyone wishing to get to the heart of Pricing strategies will be able to find it either by looking at the alphabetical checklist of concepts (pp. xi-xii) or by referring to Group E, on Understanding Positioning.

The book has been made easier to write as a result of the help and advice given by our colleagues at Cranfield. In particular, we should like to pay tribute to Professor Martin Christopher, who provided the inspiration for a number of the ideas included in the book. Without his support, this book would not have been possible.

Our students at Cranfield School of Management and other practising managers have found this approach to understanding marketing invaluable and we are pleased to be able to share it with a much wider audience. 


\section{Checklist of Concepts}

Advertising 163-7

Ansoff Matrix, the 121-6

Auditing a market $\quad 73-6$

Boston Matrix, the 127-31

Branding 149-52

Budgeting for marketing 243-6

Capital goods, marketing $\quad 57-60$

Channel management 189-92

Channel strategy $\quad 185-8$

Competitor analysis 91-5

Consumer buying behaviour 97-102

Consumer products, marketing $\quad 33-6$

Customer retention strategies 199-204

Customer service strategies 205-8

Database marketing 209-16

Developing new products $141-6$

Diffusion of innovation $117-20$

Directional Policy Matrix, the 133-9

Ethics, marketing and 27-30

Forecasting future sales 219-23

High-tech products, marketing $\quad 47-51$

Industrial products, marketing $\quad 37-40$

International market segmentation $\quad 87-8$

International marketing $\quad 17-20$ 
International product planning 226-35

Managing the sales team $\quad 179-83$

Market segmentation $\quad 83-6$

Marketing information and research 63-8

Marketing mix, the 11-16

Marketing orientation, a 7-9

Marketing planning $\quad 225-10$

Organisational buying behaviour 103-8

Organisational structure and marketing 237-42

Personal selling $\quad 175-8$

Preparing the marketing research brief and proposal $69-71$

Price, setting a 159-62

Pricing strategies 153-7

Product life-cycle, the 111-16

Public relations 169-72

Relationship marketing 21-5

Sales promotion 193-7

Service products, marketing $\quad 41-6$

SWOT, constructing a $\quad 77-82$

Trade marketing 53-5

Understanding marketing $\quad 3-6$ 